\title{
Intrusion of the extruded maxillary central incisor using skeletal anchorage system and unilateral segmental intrusion arch
}

\author{
Eun-Young Kwon', Young-Jae Baek', Soo-Byung Park², Seong-sik Kim², Yong-il Kim², Youn-kyung Choi* \\ 'Dental Clinic Center, Pusan National University Hosptial, Busan, Republic of Korea \\ ${ }^{2}$ Department of Orthodontics, School of Dentistry, Pusan National University, Yangsan, Republic of Korea
}

Patients who have a moderate periodontitis with pathologic tooth migration of maxillary incisors, it is necessary not only periodontal treatment for reduce periodontal inflammation, but also orthodontic treatment to teeth repositioning. For orthodontic treatment, it is necessary to apply less force and careful considerations of the center of resistance of the tooth and optimal force of tooth movement. At this time, the segmental arch applied only to the target teeth, is more effective and predictable, because applied force and direction can be controlled. In addition, to design the orthodontic appliance that can prevent the unwanted tooth movement that used as an anchorage is important. In recent years, various types of skeletal anchorage system have been used for preventing loss of the anchorage. We reported the patient who had extruded maxillary central incisor due to pathologic tooth migration, treated by a successful periodontal-orthodontic multidisciplinary treatment using an orthodontic appliance designed to apply less traumatic force and reduce an anchorage loss. (J Dent Rehabil Appl Sci 2019;35(3):180-90)

Key words: periodontitis; tooth migration; tooth intrusion; orthodontic wire; orthodontic anchorage

\section{서론}

최근, 심미적인 개선과 기능의 회복을 위하여 교정치료 를 원하는 성인 환자가 증가하고 있다. 그러나 성인 환자 는 국소적 혹은 전신적인 요인으로 인한 치주 조직의 염 증, 치아의 교모, 마모 및 소실과 만성적인 치주 질환을 않고 있는 경우가 많으며, ${ }^{1}$ 이로 인한 치조골 흡수와 골 내 병소가 나타나, “secondary malocclusion”이라고 표 현되는 변화된 교합을 보이기도 한다. ${ }^{2}$

생리적인 치아의 위치는 치주 조직과 더불어 교합력, 혀, 입술 등의 주변 조직으로부터의 힘에 의해 영향을 받 아 결정된다. ${ }^{3}$ 그러나 치주 조직이 치주질환 등으로 인해 파괴되면, 생리적인 치아 위치는 붕괴되며, 다양한 형태 의 병적 치아 이동이 나타난다. ${ }^{4}$

*Correspondence to: Youn-kyung Choi

Assistant Professor, Clinic Center, Pusan National University Hosptial, 179 Gudeok-ro, Seo-gu, Busan, 49241, Republic of Korea

Tel: +82-51-240-7430, Fax: +82-51-240-7706, E-mail: youngyng@hanmail.net

Received: May 27, 2019/Last Revision: June 28, 2019/Accepted: July 16, 2019
특히 치주질환으로 인해 정출되고 변위된 전치부를 보 이는 환자들은, 전치부의 조기접촉이 또 다시 외상성 충 격을 가하여, 치주조직의 파괴가 가속화되고 악순환이 심화되며, 이에 따른 심각한 기능적, 심미적 문제를 일으 킨다. 따라서 이러한 환자에서는 철저한 치태 관리를 위 한 치주 치료뿐만 아니라 교정치료가 함께 요구된다.

그러나 치주건강이 잘 관리되지 않는 상태에서 교정적 치아이동을 시행할 경우, 치주조직의 빠르고 비가역적인 파괴가 야기될 수 있으며, ${ }^{5}$ 이는 치아 이동의 여러 종류 중, 압하가 요구되는 경우 더욱 위험성이 높다. 치아의 압 하에 따른 치주조직의 반응에 대해서는 아직 논란이 존 재하여, 압하 치료시, 치주인대 섬유의 이상적인 반응으 로 재부착이 일어난다는 견해도 존재하나, ${ }^{6}$ 압하 치료가 치주낭이 깊어지도록 할 수도 있다는 상반된 주장 역시

Copyright@ 2019 The Korean Academy of Stomatognathic Function and Occlusion. (c) It is identical to Creative Commons Non-Commercial License. 
존재한다. ${ }^{7}$ 이는 철저한 치주치료가 동반되지 않는다면, 오히려 교정치료를 통해 치태 등을 치은연하로 위치 시 켜, 치주조직 파괴를 가속화할 수 있기 때문이다. ${ }^{8}$ 그러나 Melsen 등의 임상 연구에서, 교정력을 통한 치아의 이동 이 치조골과 치주조직을 적극적으로 변형시켜 치주조직 의 상태를 개선할 수 있음을 보여주었다.

교정치료 계획 수립 단계에서도 치주 질환에 이환된 성 인 환자에서는 적용할 힘의 방향과 세기에 더욱 세심한 주의를 기울여야 하며, 이 역시 압하 치료의 경우 더욱 중 요하다. 이는 골소실로 인한 치주인대 영역의 축소로 정 상적으로 지지되는 치아보다 저항중심은 더욱 치근단 측 에 위치하게 되고, 압하력은 치근단에 더 큰 압력으로 집 중되기 때문이다. ${ }^{10}$ 또한 과도한 힘이 적용될 경우, 초자 양화된 치주 조직을 제거하는 세포 활성의 부작용으로 치근 흡수, 치수조직의 변화 등의 교정치료 부작용이 나 타날 수 있다. ${ }^{11,12}$

또한 성인 환자들은, 다수의 보철 수복물이나 임플란 트 수복물이 구내에 존재하여, 전체 교합을 재구성하는 것보다 현재의 교합관계를 유지한 채로 치료하고자 하 는 전치부만의 교정치료를 진행하는 것이 현실적으로 요 구될 때가 많다. 이를 위해서는 고정원으로 사용되는 치 아에서 원치않는 움직임이 나타나 교합 변화를 야기하지 않도록 장치 디자인을 치료 계획 단계에서부터 고려하는 것이 필요하다. 최근에는 이러한 원치 않는 치아 움직임 을 예방하기 위해 미니스크류, 임플란트 수복물 등의 골 성 고정원을 이용하고 있으며, 이를 통해 고정원으로 사 용되는 치아에 가해졌던 반작용을 줄여 교정치료를 좀 더 효율적이고 간단하게 시행할 수 있다.

본 증례는 치주 질환으로 인해 수직적 치조골 흡수와 함께 정출 및 순측 변위를 보이는 상악 전치를 가진 환자
에서 골성 고정원과 분절호선을 통해 조절된 힘을 치아 에 적용하여 효율적인 압하와 위치 개선을 보인, 성공적 인 치주-교정 협력 치료이다. 이에 본 증례를 보고하고자 한다.

\section{증례보고}

\section{환자 개요 및 진단}

“앞니가 계속 내려와요"를 주소로 치주과에 최초 내원 한 54세 여자환자이다.

구강내 임상 소견상, 전반적인 부착소실로 중등도의 치주염 소견을 보였으며, 상하악 전치부와 좌우측 대구 치부의 치조골 소실이 심하였다. 특히 주소인 상악 좌측 중절치는 근심면에서 깊은 수직 골결손을 보였으며, 근심 구개측 탐침 시 치주낭 깊이가 $5 \mathrm{~mm}$ 이상으로 관찰되었 다. 또한 근심면 치은이 퇴축되었고, 치은연 역시 좌측 중 절치에서 더 수직적으로 상방에 위치하여 비심미적이었 다. 치간골 소실로 인한 중절치 사이 공극(black triangle) 이 컸다. 상악 좌측 중절치는 우측 중절치와 비교하여 순 측으로 $1 \mathrm{~mm}$ 만큼 경사이동하였으며, $1.5 \mathrm{~mm}$ 정출되었 다. 그러나 동요도는 존재하지 않았다(Fig. 1).

치은염 소견 역시 동반되었으며, 탐침 시 상하악 전치 부와 구치부에서 치은 출혈을 보였다. 상하악 우측 구치 부 관계는 양호하였으나, 상악 좌측 제 1,2 대구치들은 결 손되었다.

임상 소견과 마찬가지로 방사선 사진에서도, 상하악 전치부와 구치부의 전반적인 치조골 흡수가 관찰되었으 며, 상악 좌측 중절치가 정출되었다. 치근단 방사선 사진 에서 상악 좌측 중절치의 근심면의 깊은 수직 골결손이
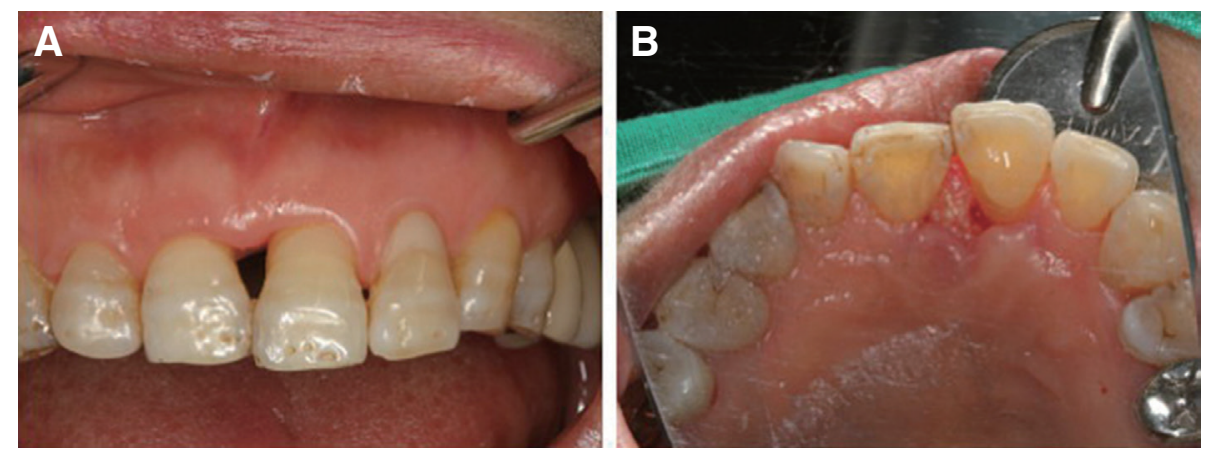

Fig. 1. Pre-treatment intraoral photographs. (A) \#21 was extruded. Large black triangle was observed between \#11 and \#21, (B) \#21 was protruded. 
관찰되며, 치근단 $1 / 3$ 지점까지 근심 치조골이 흡수된 것 을 확인할 수 있었고, 건전한 치조백선이 관찰되지 않았 다(Fig. 2).

이에 중등도의 치주염으로 진단하고, 치주과에서 염증 조절을 위한 전반적인 치주 치료를 먼저 시행한 후, 정출 된 상악 좌측 중절치를 치료하기 위한 교정치료를 진행 하기로 하였다. 교정치료를 위한 내원시마다 치주과에서 유지 관리를 받기로 하였다. 환자 역시 이러한 전반적인 과정에 동의하였다.

\section{치료 목표}

전체적인 치료의 목표와 단계는 치주 치료를 통해 치 주조직을 건강한 상태로 회복하는 것을 먼저 시행하고, 상악 좌측 대구치의 임플란트 보철 수복을 하여 좌우측 구치 수직 교합을 형성한 후, 주소인 상악 좌측 중절치를 압하하여 심미적 개선을 얻을 수 있도록 하는 것이다.

상악 좌측 중절치 압하 교정치료에 있어, 현재 좌측 중 절치의 임상 치관 길이가 길어, 상악 좌측 중절치의 상대 적 압하 및 우측 중절치의 상대적 정출을 통한 치열의 개 선은 원치 않아, 중절치만 온전히 압하하는 것이 필요하 였다. 또한 상하악 구치의 교합관계가 양호하여, 구치 관 계를 변화없이 유지하는 것 역시 중요하였다.

그러나 일반적으로 사용되는 고정식 교정장치와 연속 호선을 부착할 경우, 좌측 중절치의 압하와 더불어 주변 치아(우측 중절치 및 좌측 측절치 등)의 정출이 반작용으
로 나타나, 치료 목표인 좌측 중절치의 압하 효과가 상 쇄된다. 또한 중절치 압하를 위한 고정원을 얻기 위해 구 치까지 교정장치를 부착하여 연속호선으로 치료를 한다 면, 중절치 압하력에 대한 반작용이 구치부에 가해져, 구 치 교합이 흐트러질 가능성이 높다. 따라서 최대한의 상 악 좌측 중절치의 압하 효과와 다른 치아에 나타날 반작 용을 줄이기 위하여, 상악 좌측 제 1,2 대구치에 임플란트 보철 수복을 먼저 시행하고, 이를 골성 고정원으로 사용 하기로 하였다.

\section{치료 과정}

먼저 치주과에서 전악 치은연하 소파술과 치근 활택술 을 시행하였다. 이후 전반적인 치주염 소견이 감소하였 으며, 이로 인해 치은 탐침시 출혈 역시 사라졌다. 치주치 료가 시행된 후, 상악 좌측 구치부 임플란트 보철 수복을 위한 수술이 시행되었다.

그러나 3 개월의 치주 경과 관찰에서, 상악 좌측 중절 치의 치은 탐침시 출혈이 지속되고, 치주낭 깊이가 $5 \mathrm{~mm}$ 이상으로 관찰되어, 추가적인 치주 판막술을 시행하였 다. 판막술 시, 상악 좌측 중절치 근단부에는 3 벽성 골결 손이, 상방부에는 치간골 소실로 2 벽성 골결손이 관찰되 었다. 좌측 중절치 근심협측에서 근심구개측으로 치조 골 결손이 $8 \mathrm{~mm}$ 정도로 판단되어, bovine bone material (Bio-Oss ${ }^{\circledR}$, Geistlich Pharmaceutical, Wolhusen, Switzerland)을 이용한 골이식술을 동시에 시행하였다. 상악

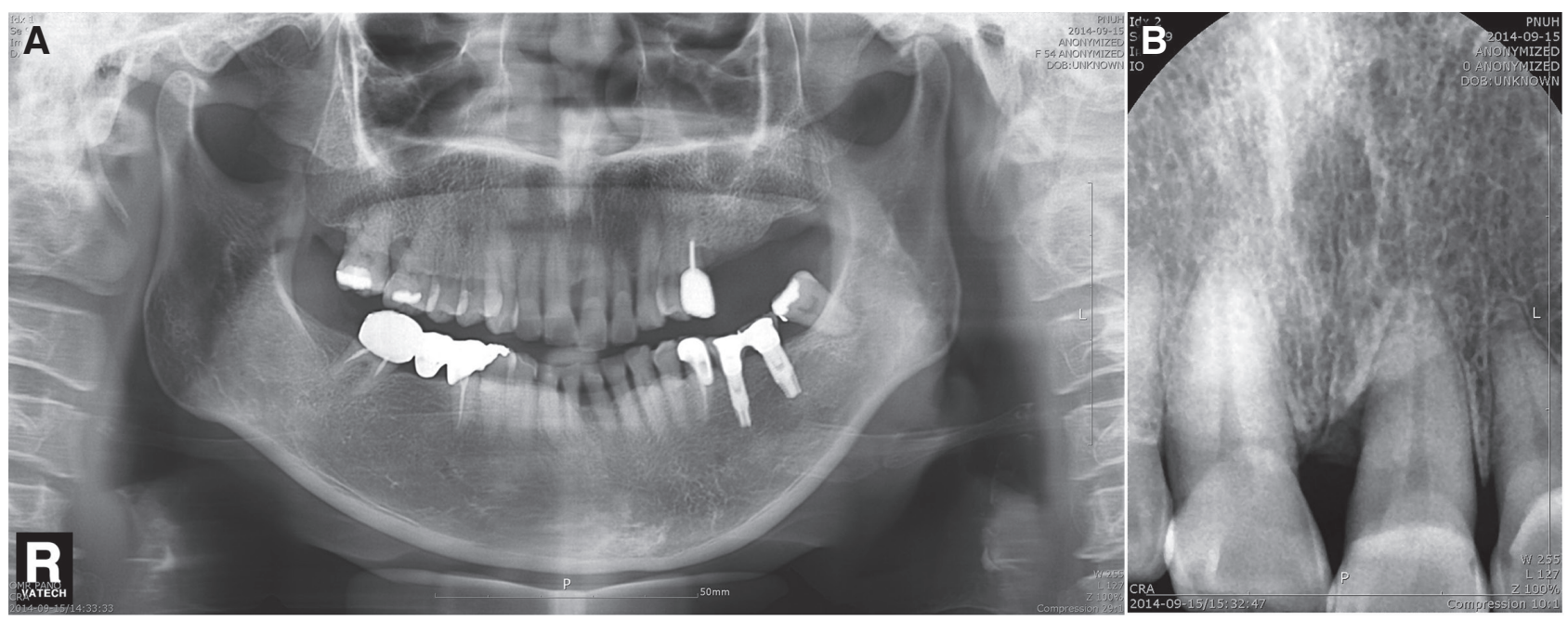

Fig. 2. Pre-treatment panoramic (A) and periapical (B) radiographs. (A) Generalized alveolar bone loss was observed. \#26 and \#27 were extracted, (B) Angular alveolar bone loss was observed on the mesial root surface of \# 21. 

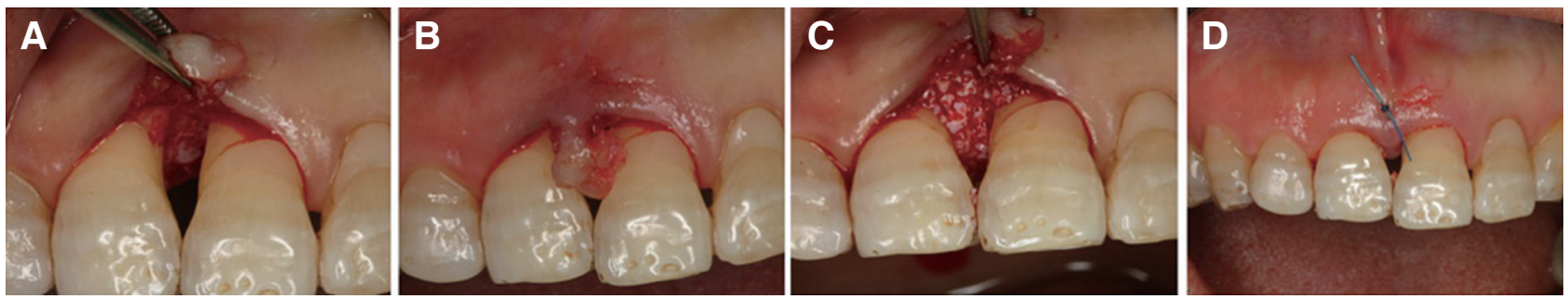

Fig. 3. Procedure of periodontal surgery with bone graft. (A) Deep periodontal pocket and alveolar bone loss were observed, (B) Flap design to preserve interdental papilla was designed, (C) During periodontal surgery, bovine bone graft $\left(\right.$ Bio-Oss ${ }^{\circledR}$ ) materials were used for bone graft.

중절치 사이의 치간골 소실이 심하여, 치간 공극(black triangle)이 컸으므로, 최대한 치간 유두를 보존하기 위한 판막 디자인을 설계하였다(Fig. 3).

3 개월 경과 관찰 시, 치주낭 깊이는 $3 \mathrm{~mm}$ 정도로 감소 하였으며, 구강위생 또한 양호하게 유지되어, 상악 좌측 중절치 압하를 위해 교정과에 내원하였다(Fig. 4).

교정과 내원시, 상악 좌측 중절치의 근심 치은연은 여 전히 우측 중절치의 치은연보다 수직적으로 상방에 위치 하여 불일치하고, 큰 치간 공극(black triangle)로 비심미 적이었다. 상악 좌측 제 1,2 대구치의 임플란트 보철 수복 이 완료된 상태였으므로, 임플란트 보철물을 골성 고정 원으로 이용하여 상악 좌측 중절치의 교정치료를 시작하 기로 하였다.

환자의 임상 모형 상에서, 미리 상악 좌측 중절치 압 하를 위한 분절호선 장치를 디자인하였다. 치조골이 소 실된 환자에서 큰 압하력과 조절되지 못한 힘이 가해질 경우, 치아의 원치않는 움직임과 치근흡수 등의 부작용 이 커질 수 있으므로, 더욱 주의가 필요하였다. 모형 상

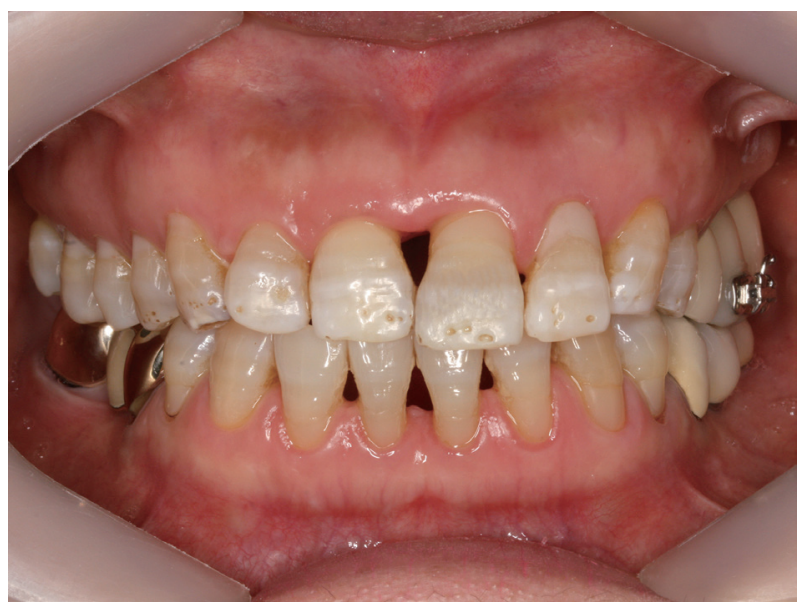

Fig. 4. Intraoral photograph before orthodontic treatment (3 months after periodontal surgery).
에서, 제1대구치의 임플란트 보철 수복물에 교정용 튜브 를 위치하여 제 1 대구치를 고정원삼아, 상악 좌측 중절치 의 치아 장축을 따르고, 저항중심을 지나는 곳에 힘이 지 나도록 설계된 cantilever intrusion wire를 제작하였다. Stainless steel 호선보다 좀 더 적은 힘으로, 지속되는 힘 을 발휘하는 TMA (beta-Titanium wire) 호선을 사용하 였으며, $0.016 \times 0.022$-inch TMA 호선을 이용하였다. 단 근치에 적용되는 압하력의 최적힘은 $12-20 \mathrm{gm}$ 정도라 고 알려져 있으며, ${ }^{13}$ 본 환자는 치조골이 소실되었으므로, 좀 더 적은 힘을 적용하기 위해 gauge (DT-500G, TECLOCK Co. Ltd., Nagano, Japan)를 이용하여, $12 \mathrm{gm}$ 의 힘이 적용되도록 호선을 활성화시켜 제작하였다(Fig. 5).
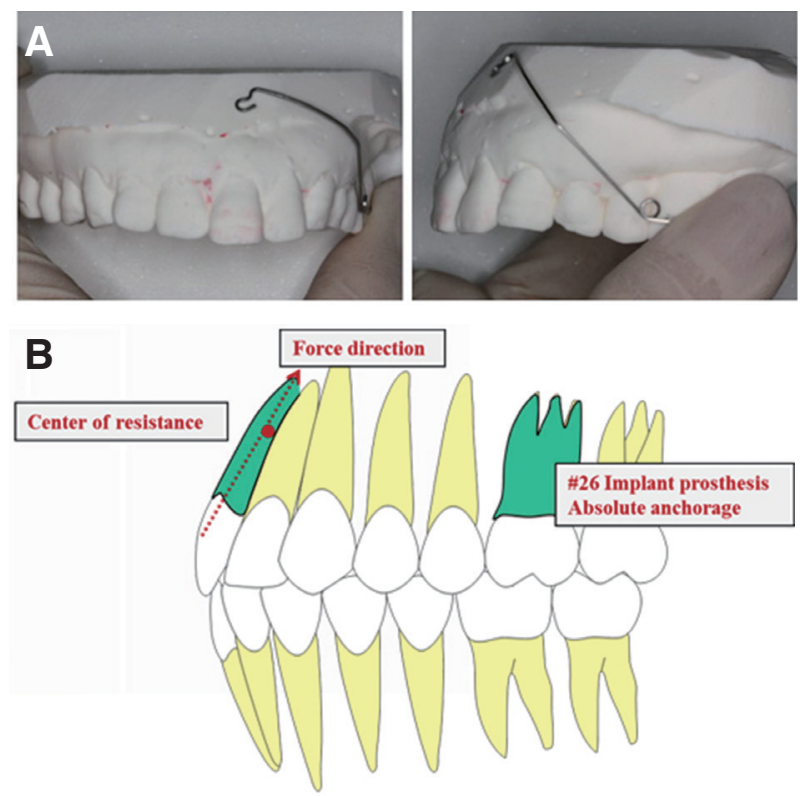

Fig. 5. Segmental intrusion arch design. (A) $0.016 \times 0.025-$ inch TMA wire was used for segmental intrusion arch, (B) The segmental intrusion arch was designed to allow the force to pass through the center of resistance of \#21. 
환자 내원시, 환자의 상악 좌측 중절치에 $\mathrm{MBT}$ prescription, $0.022 \times 0.026$-inch slot의 세라믹 브라켓(Clippy-C, Tomy Inc., Futaba, Fukushima, Japan)과 좌측 제1 대구치 임플란트 보철 수복물에 $0.022 \times 0.026$-inch slot 의 conventional 메탈 튜브(Tomy Inc., Futaba)를 부착하 고, 미리 제작한 $0.016 \times 0.022$-inch TMA 분절 호선을 적용하였다(Fig. 6). 이후 교정과에 매달 내원할 때마다, $12 \mathrm{gm}$ 만큼의 힘을 새로 적용하였으며, 변화하는 상악 좌측 중절치의 저항중심과 장축에 맞추어 cantilever 분 절호선의 $\mathrm{arm}$ 역시 조금씩 수정하였다. 상악 좌측 중절치 는 점차 압하와 설측이동되었다.

교정과에 내원할 때마다 치주과에서 치주처치 또한 같
이 시행하여, 철저한 구강위생이 유지되도록 하였다. 치 료 기간 동안 치주낭 깊이는 $3 \mathrm{~mm}$ 이하로 유지되었으며, 탐침시 치은출혈은 관찰되지 않았다.

5 개월 뒤, 상악 좌측 중절치의 절단연이 상악 우측 중 절치의 절단연과 조화를 이루었으며, 협설측 절단연의 위 치 역시 일치하였다(Fig. 7). 이후 다소 회전된 상악 우측 측절치의 개선 역시 원하여, 모형 set-up 후, 투명 가철성 장치를 이용해 상악 우측 측절치 회전을 개선하였다. 또 한 좌측 중절치의 압하로 상대적으로 임상치관이 길어보 이는 좌측 측절치를 치아 모형상에서 $0.5 \mathrm{~mm}$ 절단연을 삭제하여 투명 가철성 장치를 제작하고, 이를 착용하시 도록 하여 간단히 개선하였다. 이에 고정식 유지장치를
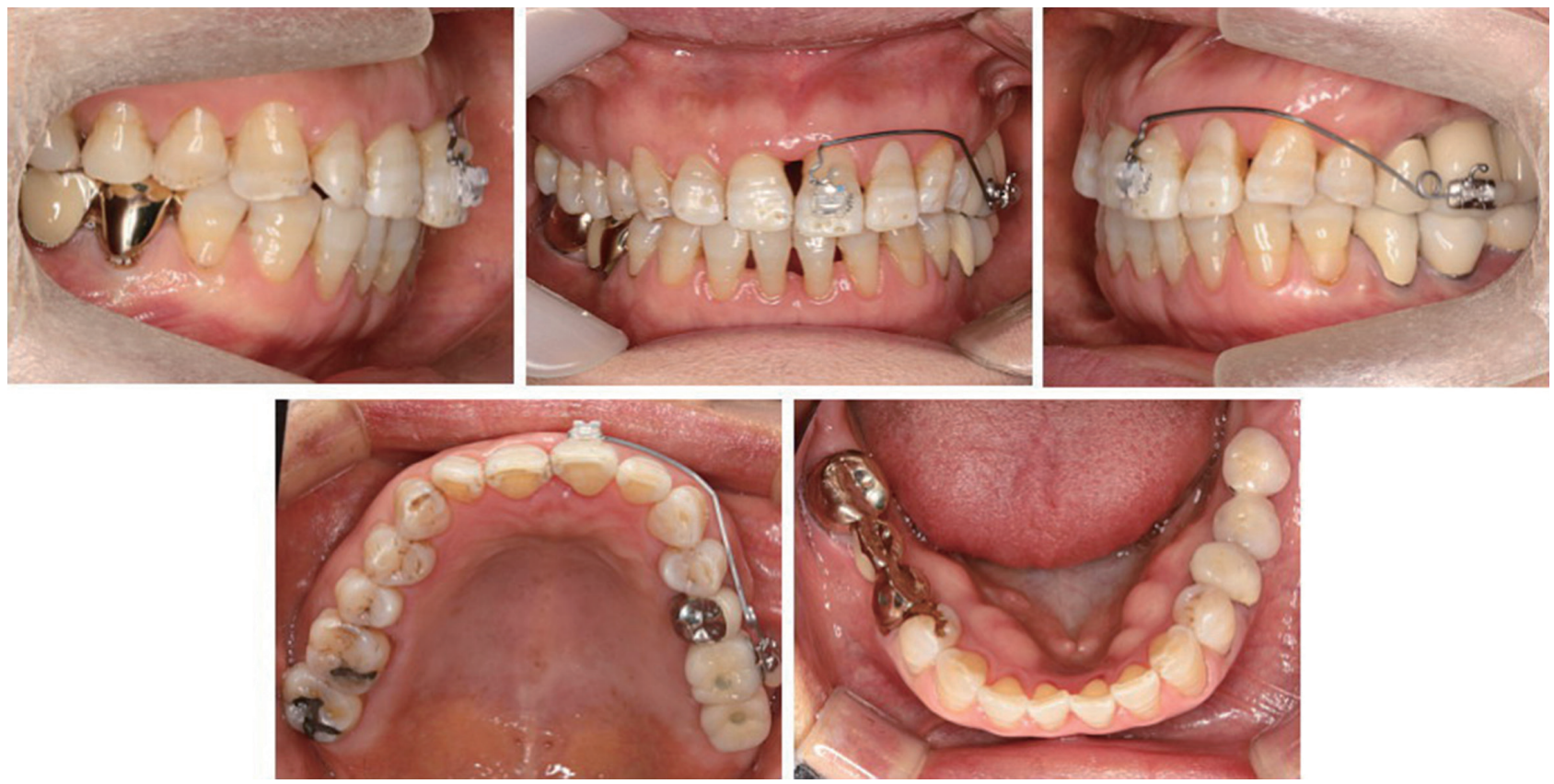

Fig. 6. Intraoral photographs of orthodontic treatment (initiation, bracket bonding). The segmental intrusion arch was applied to \#21 and 26. The segmental intrusion arch was activated and pulled toward bracket to apply a force of $12 \mathrm{gm}$.
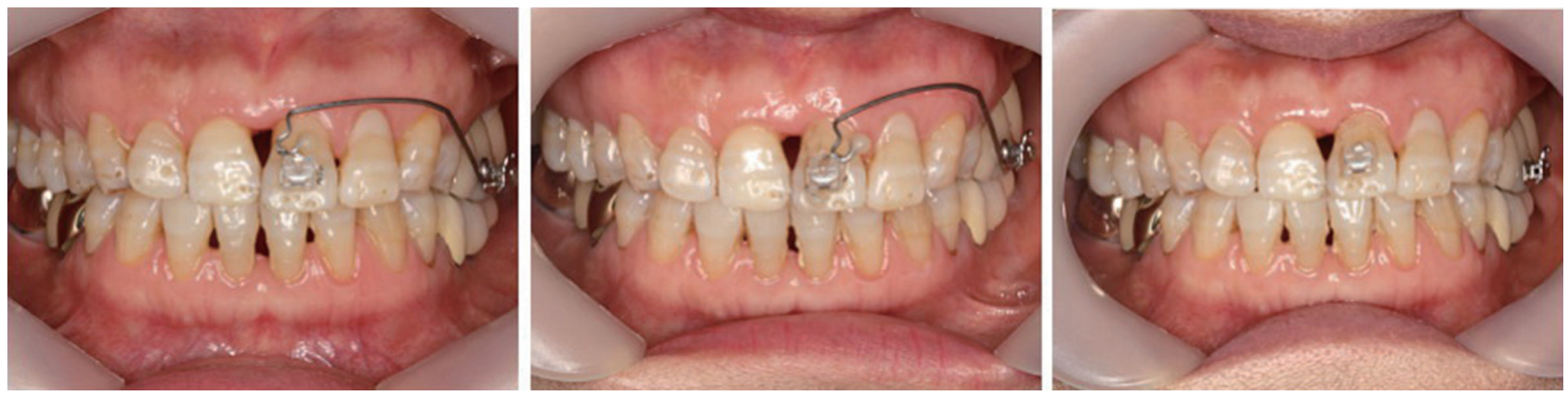

Fig. 7. Progression of orthodontic treatment (during 5 months). \#21 was gradually intruded by segmental intrusion arch. 
상악 절치 설면에 부착하고, 치료를 종결하였다. 총 교정 치료기간은 10 개월이었다(Fig. 8).

이후 치주과와 교정과에 정기적으로 내원하여 유지 관 리 시행하고 있다.

\section{치료 결과}

치주 치료와 교정 치료 이후, 주소였던 상악 좌측 중절 치가 압하되어, 심미적인 상악 치열을 보였으며, 상악 전 치의 절단연이 미소선과 조화를 이루게 되었다. 구치 교 합관계의 변화나 상악 다른 전치의 정출 등의 부작용은 관찰되지 않았으며, 목표로 했던 상악 좌측 중절치가 1 $\mathrm{mm}$ 설측으로, $1.5 \mathrm{~mm}$ 압하되었다. 압하 치료를 진행하 였음에도, 상악 좌측 중절치의 치은연이 치아를 따라 상 방 이동하지않아, 우측 중절치와 좀 더 조화를 이루게 되 었으며, 치간 공극(black triangle)의 크기가 감소하였다 (Fig. 9A, 9B) 치주낭 깊이 증가 역시 나타나지 않아, 치 주낭 탐침 시 모든 부분에서 $3 \mathrm{~mm}$ 이내의 깊이를 보였 다. 전치간 교합은 수직, 수평피개 모두 $1 \mathrm{~mm}$ 로 양호하 였다. 구치부 관계는 초진시와 마찬가지로 유지되어 긴 밀한 상하악 교합 관계를 보이고 있다.

치근단 방사선 사진에서도 상악 좌측 중절치의 압하
를 확인할 수 있으며, 치주낭의 깊이가 초진시와 비교하 여 치료 후 치근단 $1 / 2$ 지점에 위치하여 치주낭이 깊어지 지 않았으며, 치주낭이 얕아져 완만한 경사를 보이는 것 을 확인할 수 있다. 또한 건전한 치조백선이 관찰된다. 적 절한 힘 조절로 과도한 치근의 흡수는 나타나지 않았다 (Fig. 9C, 9D).

이후 4년간의 유지관찰을 시행하였으며, 압하된 상악 좌측 중절치 위치 역시 잘 유지되었다. 오히려 상악 좌 측 중절치의 근심 치은연의 위치가 개선되었으며, black triangle 역시 감소하였다. 치주낭 탐침 시 모든 부분에서 $3 \mathrm{~mm}$ 이내의 깊이로 유지되었다. 치근단 방사선 사진에 서도 건전한 치조백선이 관찰되며, 치주낭의 기저부의 위 치가 조금 더 개선된 것을 관찰할 수 있다(Fig. 10).

\section{고찰}

과거 치주질환이 있는 성인 환자에서 교정치료를 시행 하는 것이 치주조직의 염증과 치조골의 급속한 파괴를 야기하며, 교정 치료 자체가 치주 조직을 악화시키는 것 이 아닌가에 대한 의문이 제기된 적이 있었다. ${ }^{14}$

그러나 치주염의 진행과 재발에 관여하는 것은 치주낭 내의 세균성 치태로 알려져 있으며, ${ }^{15}$ 치주질환이 없는 건
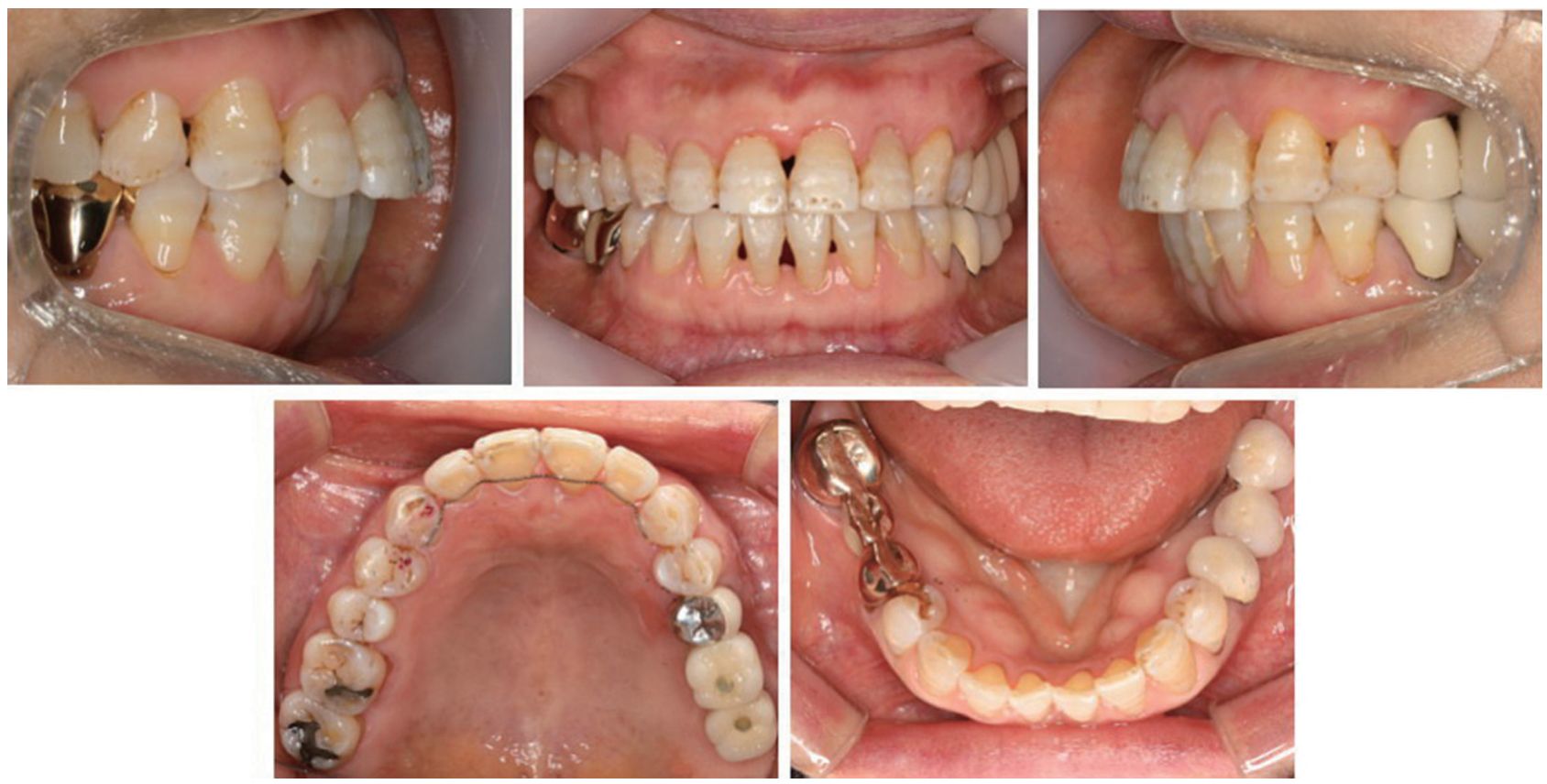

Fig. 8. Post-orthodontic treatment (bracket removal) intraoral photographs. \#21 was intruded and retracted. Fixed retainer was placed on maxilla anterior teeth (\#13-23). 

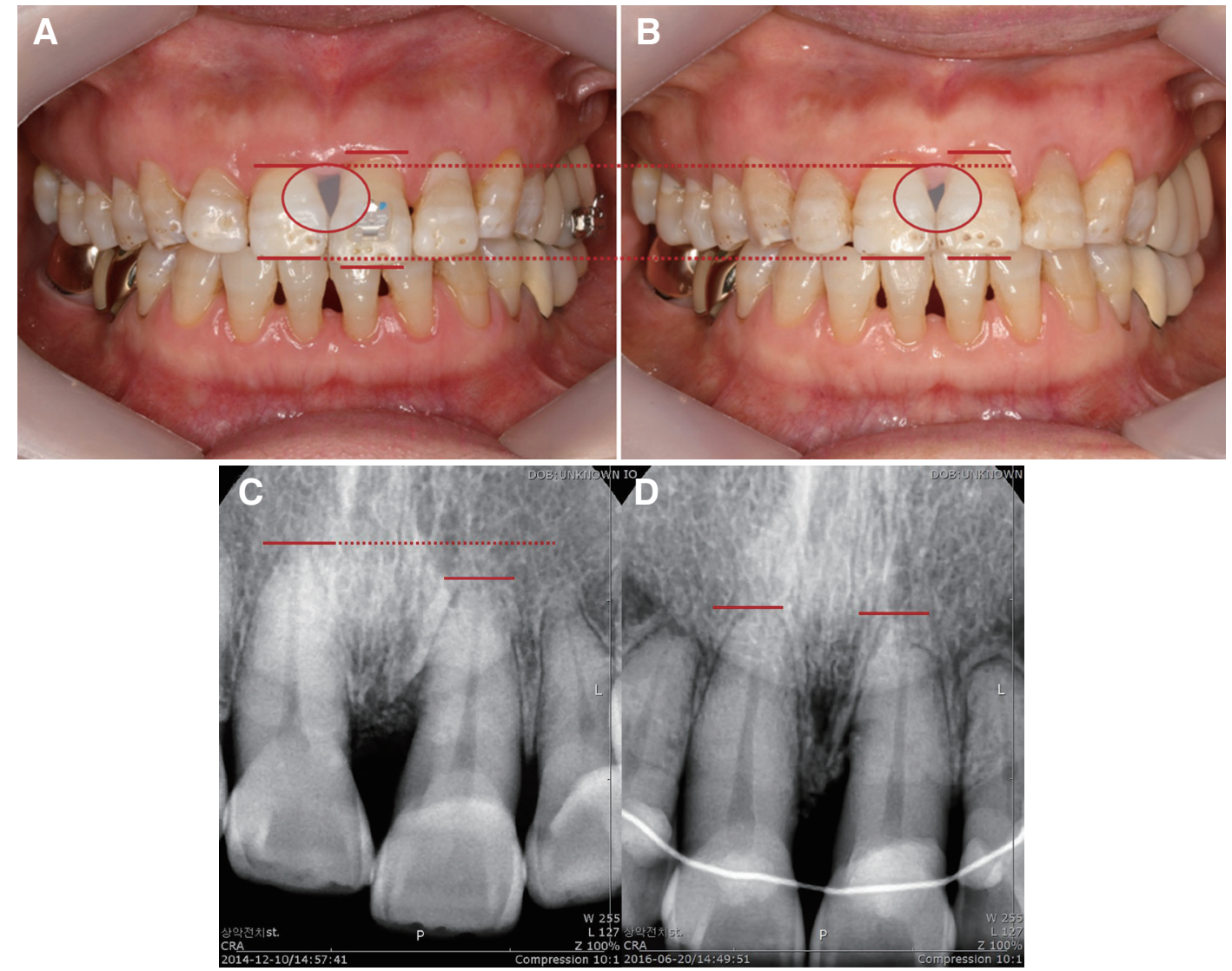

Fig. 9. Comparisons of pre-treatment (A, C) and post-treatment (B, D). (A, B) Intraoral photographs. \#21 was intruded. The gingival margin of \#21 was maintained during orthodontic treatment and black triangle between \#11 and \#21 was reduced. (C, D) Periapical radiographs. After orthodontic treatment, \#21 was intruded.

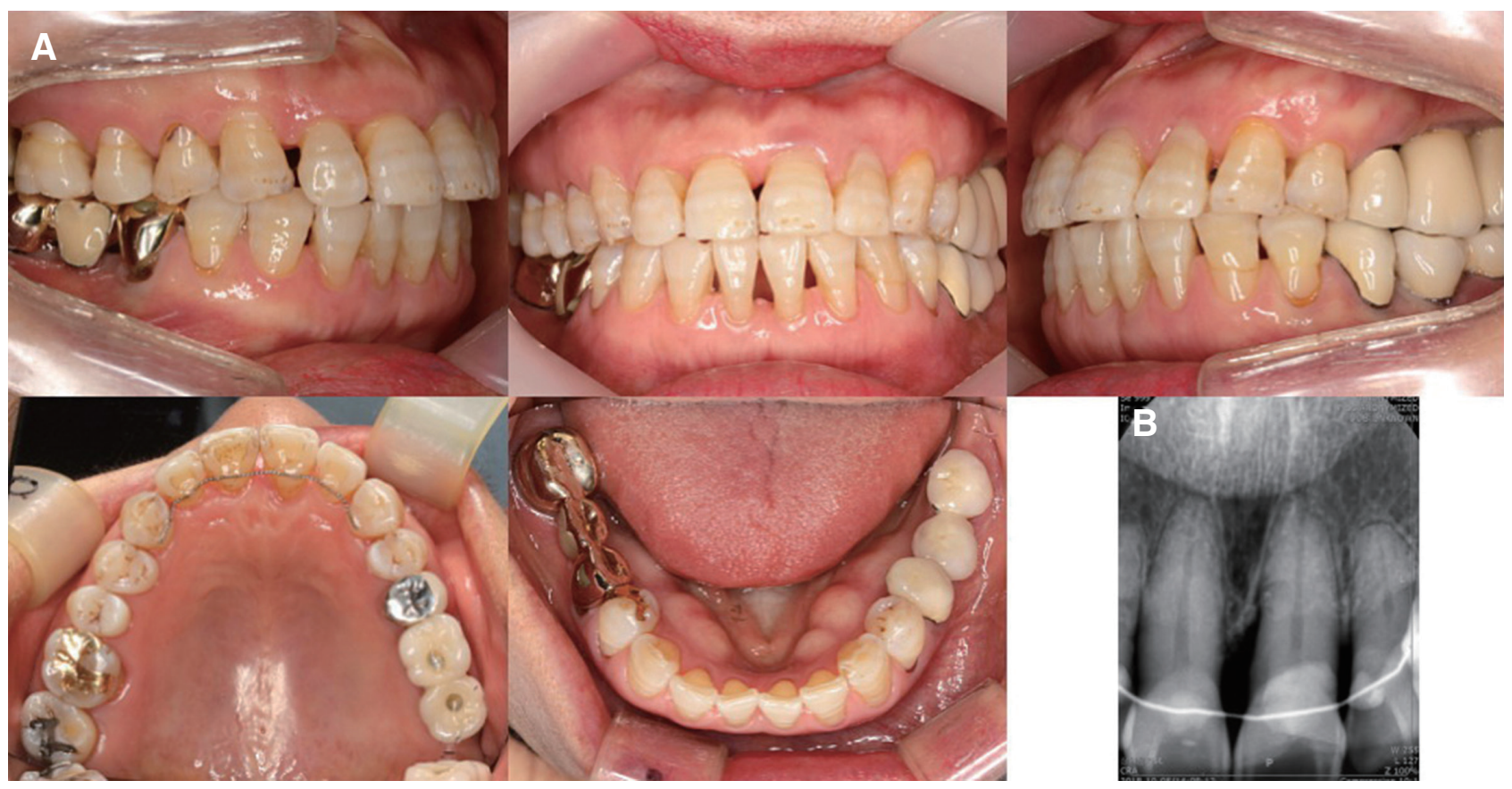

Fig. 10. Intraoral photographs (A) and periapical radiograph (B) for 4-year retention period. 
강한 환자에서 교정치료로 나타나는 치주 조직의 파괴 는 가역적이며 치주질환이 있는 환자에서도 치주치료의 선행과 철저한 구강위생으로 세균성 치태가 잘 관리된다 면, 교정치료 시 급격한 조직의 파괴를 막을 수 있다고 받 아들여진다. ${ }^{5,6}$ 또한 교정치료를 통해서 치열 총생과 비정 상적인 치아 위치의 개선이 이루어져 정상적인 교합으로 기능이 회복되고 구강위생관리가 쉬워질 수 있다. 그리고 적절한 보철 치료가 가능해져 더욱 바람직한 힘이 부여 되어, 결국 치아와 치주조직의 안정을 얻을 수 있다. 상기 환자는 중등도의 치주염을 보이는 환자로서, 교정치료 전 전악에 걸친 치은연하 소파술과 치근활택술을 시행하 였고, 3 개월의 유지기간 이후 상악 전치부에는 깊은 치주 낭이 관찰되어 추가적인 치주 판막수술과 골이식술 역시 같이 시행되었다. 이후 3 개월 경과를 관찰하였으며, 치은 탐침 시 출혈이 관찰되지 않았고, 치주낭의 깊이가 $3 \mathrm{~mm}$ 이하로 유지되어 교정치료를 시작하였다. 또한 교정치료 를 위해 내원할 때마다 치주과에서 치태 관리를 시행하 여 파괴적인 치주 조직 변화가 관찰되지 않았다.

압하 치료를 시행한 환자에서의 치주조직의 반응에 대 해서는 다양한 연구결과가 있다. 압하 치료시, 철저한 치 주치료를 시행하고, 조절된 교정력을 적용할 경우, 치아 는 압하되고, 치조골 변연부는 치관측으로 이동한다는 보고가 있으나, ${ }^{6,9}$ 치아 이동량의 $80 \%$ 정도로 치은연이 치아 이동과 같은 방향으로 이동하여 임상 치관이 길어 진다는 상반된 주장 또한 존재한다. ${ }^{7}$ 본 증례에서는 1.5 $\mathrm{mm}$ 상악 좌측 중절치가 압하되었으나, 치료 종결시 치 은연의 위치는 치아와 함께 상방 이동하지 않고 유지되 어 상대적으로 임상치관 길이가 짧아졌으며, 치주낭 탐 침 시 깊이 역시 $3 \mathrm{~mm}$ 이하로 유지되어 치조골 변연부가 상대적으로 치관측으로 이동된 것으로 판단된다. 이는 치근단 방사선 사진을 통해서도 확인할 수 있으며, 초진 시 상악 우측 중절치보다 치관측으로 위치하던 좌측 중 절치의 치근단 위치가 압하 치료 이후에 일치하는 것이 관찰되며, 이때 상악 좌측 중절치 근심면의 치주낭의 기 저부의 위치는 초진시 치아의 근단부 $1 / 3$ 에 위치하였으 나, 치료 종결 후 치관측으로 상당량 이동되어 치근 $1 / 2$ 지점에 위치한다. 이러한 결과는 본 증례에서 치근활택 술 등과 더불어 수직골결손 부위에 골이식술을 함께 시 행한 결과로 판단된다.

교정치료를 앞둔 환자의 골변화를 유발할 수 있는 술 식의 시행 시기에 대한 논쟁이 있으나, 본 증례에서는 2010년 발표된 Re 등 ${ }^{16}$ 의 논문을 토대로 교정치료 전에
판막술과 함께 골이식술을 교정치료 전에 먼저 시행하였다.

치주 질환이 있는 성인의 교정치료는 건강한 치주 조직 을 가지는 젊은 성인 환자의 치료보다 치주 관리 측면을 제외하고서도, 삼차원상에서 원하는 치아의 움직임을 얻 기 위해 더욱 많은 고려사항이 있다.

치주 질환을 가진 환자의 경우 치조골의 지지가 감소 하게 되고, 이에 따라 저항중심은 치근단 방향으로 이동 하게 된다. 따라서 교정치료 기간동안 힘의 강도와 적용 의 위치는 적절하게 적용, 조절되어야 한다. ${ }^{9}$ 저항중심 (center of resistant)이 치근단 방향으로 이동된 경우 모 멘트 $(\mathrm{M}) /$ 힘(F) 비 또한 정상적인 경우에 비해 적게 변경 되어야 한다. 이를 위해, 적용되는 힘은 건강한 치주조직 의 지지를 받는 경우보다 적어야 하며, 적은 힘에도 치아 가 큰 반응을 보이므로, 정상적인 경우에 비해 모멘트를 크게 적용하여야 한다. 본 증례에서는 보다 3 차원적으 로 조절된 힘을 적용하기 위해서 분절호선을 통한 forcedriven mechanics를 이용하였다. ${ }^{17}$ 제 1 대구치와 중절치 에만 적용된 분절호선은, 모든 치아에 장치를 부착하여 작용하는 shape-driven mechanics의 연속 호선에서보다 브라켓 간에 삽입된 호선의 길이가 증가하여 같은 변위 량에서 더 적은 힘을 치아에 전달하게 된다. 또한 shapedriven mechanics의 연속 호선에서 공간을 폐쇄할 때 변 수로서 작용할 수 있는 호선과 브라켓 사이의 마찰력이 나 계산하기 어려운 여러 치아에서 동시다발적으로 일 어나는 다양한 힘의 역할을 배제할 수 있으며, 치아를 이 동하고자 하는 방향과 힘의 크기를 조절할 수 있으므로, 더욱 정확한 치아 이동이 가능하다. ${ }^{18}$ 상기 환자는 다른 상악 절치나 구치의 이동으로 교합변화가 일어나는 것 을 차단하고자 하였기에, 상악 좌측 중절치에만 적용되 는 힘이 필요하여, 분절호선이 더욱 적당하다고 판단하 였다. 이 때 각형 분절호선을 전치부 브라켓 슬롯에 결찰 할 때 유의해야할 사항으로 전치(\#21)에 가해질 수 있는 토크(torque, 3rd order)이다. 토크는 전치부에서는 치관치근의 협설측 방향 움직임으로, 치아의 뒤틀림에 관여하 게 되는데, 이는 각형호선과 브라켓 슬롯이 만나 브라켓 슬롯에 가해지는 모멘트로 발현된다. 이는 브라켓 슬롯 에 딱 맞는 크기의 호선이 적용될 경우 더욱 커질 수 있으 며, 슬롯과 호선 크기에 차이가 있다면 상쇄되는 힘(play) 이 존재할 것이다. 따라서 분절호선 제작시, 토크가 필요 한 상황이라면, 브라켓 슬롯의 크기에 최대한 맞는 호선 을 선택하거나, 호선에 추가적인 토크를 부여해야 한다. 그러나 토크의 발현을 원하지 않는 상황이라면, 원형호 
선을 사용하거나, 본 증례처럼 각형호선을 브라켓 슬롯 에 결찰하지 않고, 브라켓 상방 hook에 결찰용 호선으로 묶어 예방할 수 있다.

또한 분절호선은 호선상의 loop 등의 구조가 있으므로, 구강 위생 관리가 어려울 수 있어 치주 질환이 있는 환자 에서 사용할 경우, 더욱 철저한 치태 관리가 필요하다.

본 증례에서는 치료의 목표였던 분절 호선과 골성 고 정원을 이용한 상악 좌측 중절치 압하 치료 후, 환자와 추가 상담을 통해 좌우측 측절치 역시 개선하기로 하였 으며, 투명 교정 장치를 이용하였다. 좌측 측절치의 경우 좌측 중절치와는 다르게 치조골 흡수를 보이지 않아 치 주상태가 양호하여 잘 조절된 최적의 힘, 증가된 모멘트 의 필요성 등이 낮았고, 순측 변위를 보이지 않은 채, 0.5 $\mathrm{mm}$ 정도의 단순 압하 이동만을 필요하여 따로 분절 호선 을 사용하지않고 우측 측절치 개선 시 사용한 투명 교정 장치를 함께 이용하였다.

치주 질환이 있는 환자에서 또한 고려해야 할 사항으 로 치료를 시작하기 전에 잔존 치아 수와 현재의 교합을 고려하여 안정적인 고정원을 설정하고 필요시 이를 보강 하는 것이다. 본 증례에서는 고정원의 강화를 위해 상악 좌측에 식립된 임플란트 보철 수복물을 이용하였다. 임 플란트 보철물이나 미니 스크류 등과 같은 골성 고정원 은 반작용이 없는 확실한 고정원을 제공하므로, 원치 않 는 고정원 치아의 이동을 방지할 수 있다.

교정장치를 제거한 후 일정기간 동안 보정이 필요하다. 특히 치은 섬유의 뒤틀림 등이 나타나는 회전 등에 영향 을 주는 상치조 탄성섬유는 재형성이 매우 늦게 일어나 기 때문에 1년이 지날 때까지 회귀 현상이 나타날 수 있 으므로 세심한 주의가 필요하다. ${ }^{19}$ 또한 성인에서는 교정 력에 대한 치주조직의 적응이 늦게 일어나며, 치주염이 심했던 환자일수록 많은 회귀현상이 나타난다는 것을 알 아야 한다. ${ }^{20}$

\section{결론}

중등도의 치주염을 보이는 환자에서, 치주과와 연계한 치태관리와 구강내 부정교합의 개선은 진단과 치료 계획 단계에서부터 긴밀히 협력되어야 한다. 또한 교정 치료 계획을 수립함에 있어서 원하는 치아의 이동 방향과 적 절한 힘의 적용을 위한 세심한 고려가 필요하다. 본 증례 에서는 치주염으로 인한 치아의 병적 이동으로 상악 절 치의 정출과 돌출이 나타났으며, 조절된 힘을 적용하기
위한 교정 장치 디자인으로 효율적인 치주-교정 치료 결 과를 가져올 수 있었다.

\section{Acknowledgements}

본 연구는 2018년도 부산대학교 병원 임상연구비 지원 으로 이루어졌음.

\section{ORCID}

Eun-young Kwon https://orcid.org/0000-0001-9555-0360

Young-Jae Baek https://orcid.org/0000-0003-3226-8266

Soo-Byung Park https://orcid.org/0000-0002-9774-9178

Seong-sik Kim https://orcid.org/0000-0003-1988-6043

Yong-il Kim https://orcid.org/0000-0003-3889-2545

Youn-kyung Choi https://orcid.org/0000-0003-1491-2986

\section{Reference}

1. Disease Statistics. Healthcare Bigdata Hub. Wonju: Healthcare Insurance Review \& Assessment Service. Available from: http://opendata.hira.or.kr/op/opc/ olapHifrqSickInfo.do (updated 2019 May 24).

2. Melsen B. Adult Orthodontics: Aetiology. 3rd ed. West Sussex; Wiley-Blackwell; 2012. p. 48-50.

3. Proffit WR, Field HW, Sarver DM. Contemporary Orthodontics. 4th ed. New York; Elsevier; 2007. p. 142-4.

4. Towfighi PP, Brunsvold MA, Storey AT, Arnold RM, Willman DE, McMaham CA. Pathologic migration of anterior teeth in patients with moderate to severe periodontitis. J Periodontol 1997;68:96772.

5. Artun J, Urbye KS. The effect of orthodontic treatment on periodontal bone support in patients with advanced loss of marginal periodontium. Am J Orthod Dentofac Orthop 1988;93:143-8.

6. Melsen B, Agerbaek N, Erikson J, Terp S. New attachment through periodontal treatment and orthodontic intrusion. Am J Orthod Dentofac Orthop 1988;94:104-16.

7. Erkan M, Pikdoken L, Usumez S. Gingival response to mandibular incisor intrusion. Am J Orthod Dentofacial Orthop 2007;132:143.e9-13. 
8. Ericsson I, Thilander B, Lindhe J, Okamoto H. The effect of orthodontic tilting movements on the periodontal tissures of infected and non-infected dentitions in dogs. J Clin Periodontol 1977;4:278-93.

9. Melsen B, Agerbaek N, Markenstam G. Intrusion of incisors in adult patients with marginal bone loss. Am J Orthod Dentofacial Orthop 1989;96:232-41.

10. Ryph P. Ultrastructural vascular changes in pressure zones of rat molar periodontium incident to orthodontic movement. Scand J Dent Res 1972;80:30721.

11. Weltman B, Vig KW, Fields HW, Shanker S, Kaizar EE. Root resorption associated with orthodontic tooth movement: a systematic review. Am J Orthod Dentofacial Orthop 2010;137:462-76.

12. Mostafa YA, Iskander KG, El-Mangoury NH. Iatrogenic pulpal reactions to orthodontic extrusion. Am J Orthod Dentofac Orthop 1991;99:30-4.

13. Steigman S, Michaeli Y. Experimental intrusion of rat incisors with continuous loads of varying magnitude. Am J Orthod 1981;80:429-36.

14. Thilander B. Orthodontic tooth movement in peri- odontal therapy. In: Textbook of Clinical Periodontology. Copenhagen; Munksgaard; 1989. p. 450 500 .

15. Alstad S, Zachrisson BU. Longitudinal study of periodontal condition associated with orthodontic treatment in adolescents. Am J Orthod 1979;76:277-86.

16. Re S, Corrente G, Abundo R, Cardaropoli D. Orthodontic treatment in periodontally compromised patients: 12-year report. Int J Periodontics Restorative Dent 2000;20:31-9.

17. Burstone CJ, Goldberg AJ. Maximum forces and deflections from orthodontic appliances. Am J Orthod 1983;84:95-103.

18. Burstone CR. Deep overbite correction by intrusion. Am J Orthod 1977;72:1-22.

19. Reitan K. Tissue rearrangement during retention of orthodontically rotated teeth. Angle Orthod 1959;29:105-13.

20. Ericsson I, Thilander B. Orthodontic relapse in dentitions with reduced periodontal support: an experimental study in dogs. Eur J Orthod 1980;2:51-7. 


\section{골성 고정원과 편측 분절호선을 이용한 정출된 상악 중절치의 압하 치료}

\section{권은영 ${ }^{1}$, 백영재 ${ }^{1}$, 박수병 ${ }^{2}$, 김성식 ${ }^{2}$, 김용일 ${ }^{2}$ 최윤경 ${ }^{1 *}$}

${ }^{1}$ 부산대학교병원 치과진료센터

${ }^{2}$ 부산대학교 치의학전문대학원 치과교정과

병적 치아 이동된 상악 전치를 가진 중등도 치주염 환자에서는 치태 관리를 통한 치주 염증의 해소뿐만 아니라 치아를 재 위치 시키기 위한 교정치료가 함께 필요하다. 이 때의 교정치료는 더 적은 힘의 적용과 치아의 저항중심, 최적의 힘 등을 세심하게 고려해야 하는데, 이동하고자 하는 치아에만 적용되는 분절호선은 이동의 예측성을 높여주고, 힘을 조절할 수 있어 보다 효율적이다. 또한 교정치료 시, 고정원으로 사용되는 치아의 원치 않는 움직임을 차단하여 구치 교합 상태를 유지할 수 있는 장치 설계가 필요하며, 이를 위해 다양한 종류의 골성 고정원이 사용될 수 있다. 본 증례에서는 정출되고 변위된 상악 전치를 가진 환자에서, 철저한 치주 치료와 적절한 힘과 역학이 설계된 교정 장치로, 양호한 치료 결과를 얻 을 수 있었으므로, 소개하고자 한다.

(구강회복응용과학지 2019;35(3): 180-90)

주요어: 치주염; 치아 이동; 치아 압하; 교정 호선; 고정원 